\title{
THE IFE STONE CARVINGS
}

IFE, a Yoruba town 80 miles E. of Ibadan, is called by the natives the "cradle of the universe."

From this town the whole human race is supposed to have sprung into existence. The ruler, for the last 200 years at least, has been entitled the Oni, and he is the spiritual but not the temporal head of the Yoruba nationa sort of Pagan Pope.

Unfortunately, owing to the lack of records, the origin of the Yoruba race is hard to trace. The only evidence that I know of comes from the Arabic chronicles of Bello, first Sultan of Sokoto, who reigned about 1820 A.D.

Therein it is stated that the Yorubas are supposed to originate from the children of Canaan, who were of the tribe of Nimrod. Driven from Arabia by Yaa Rooba, son of Kahtan (who he was I don't know), they settled first between Egypt and Abyssinia, and from there they are supposed to have been driven gradually south-westwards across Africa until they reached the land they now occupy.

The Yoruba now is certainly a negroid, but in many of their customs distinct Egyptian traces may be seen, notably in the texture of the wraps, and the way in which they are arranged, for the burial of the dead. Amongst them also are traces of Egyptian features.

So much for past history, but the purpose of this article is to endeavour to trace by whom and when the stone carvings now visible in the town were executed.

As is known, the Yoruba of the present day has no knowledge of working in stone. In no other town in the country do such relics exist. They are one and all regarded by the present generation as sacred and hedven-sent.

To the observant eye, traces of a former great walled town 


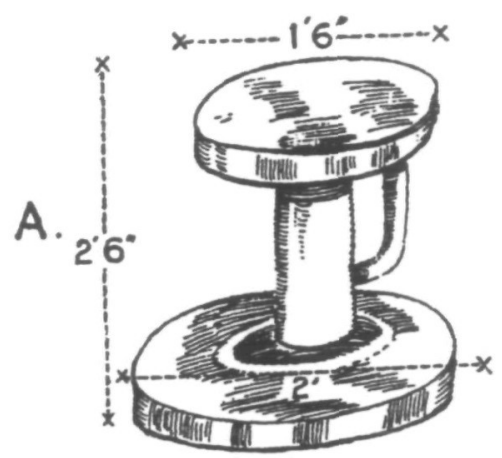

B.
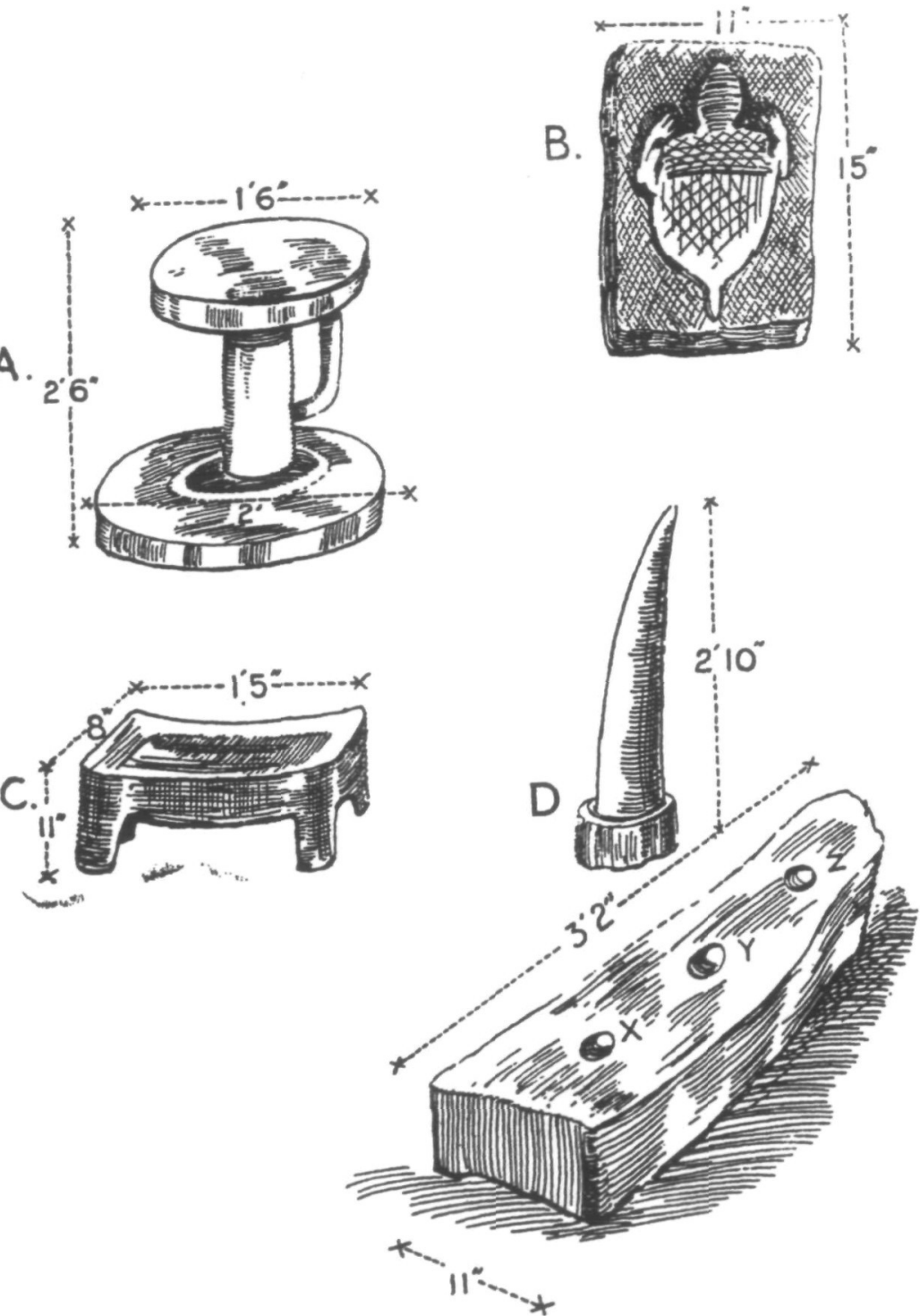

A. Stool or thble of polished quarts, which looks thke marble.-B. Gnite slab with tortoine in relief,-C. Granite etter-A. B. and C. are in a fetizh grove behind the hoorse of a so-called Christion in the centre of Ife-D. There ere many tones of these kinds and shapes abont. They are all of gneisaic gnanite. The holes marked $x, y, z$ are in in diameter by $6^{\prime \prime}$ deep. 

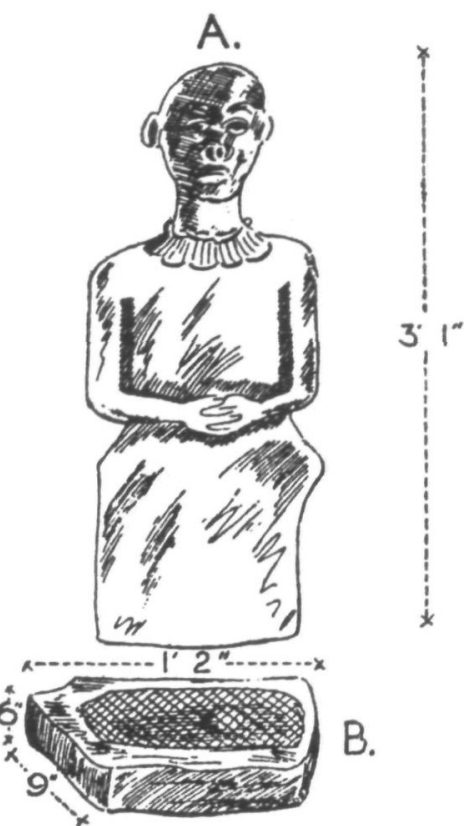

B.
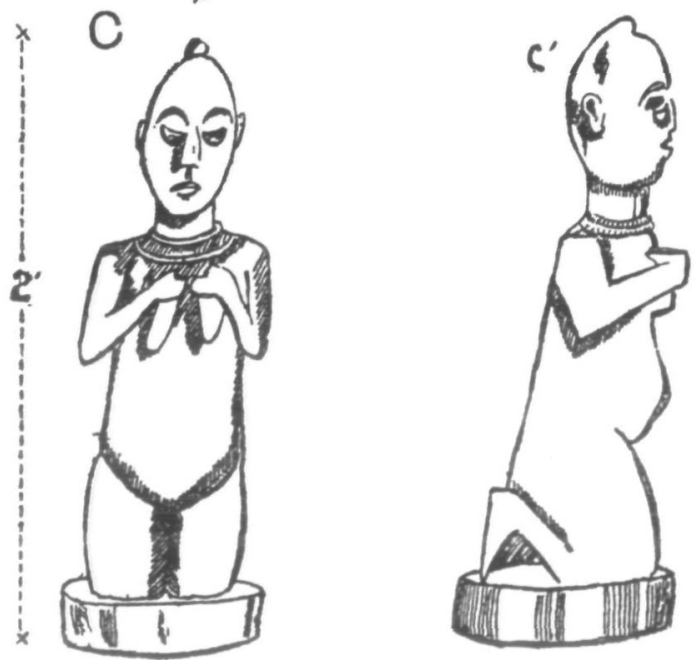

A. Granite frgure of woman with negro features. It appears to be very old, and in much worn from exposure. Now in fetich grove half-a-mile south of the Oni of Ife's residence. $-B$. Hollowred-out gmnite shab standing at base of statuette A. -C. Done in sandstone. This image is now held very acred and is worshipped 28 the goddess of the breeze. Take her away, and Ife will get no more wind. Note the features, which are scarcely negroid, and the top-knot which is of the kind in vogue to-day. $-C^{\prime}$. Side view of sume. 


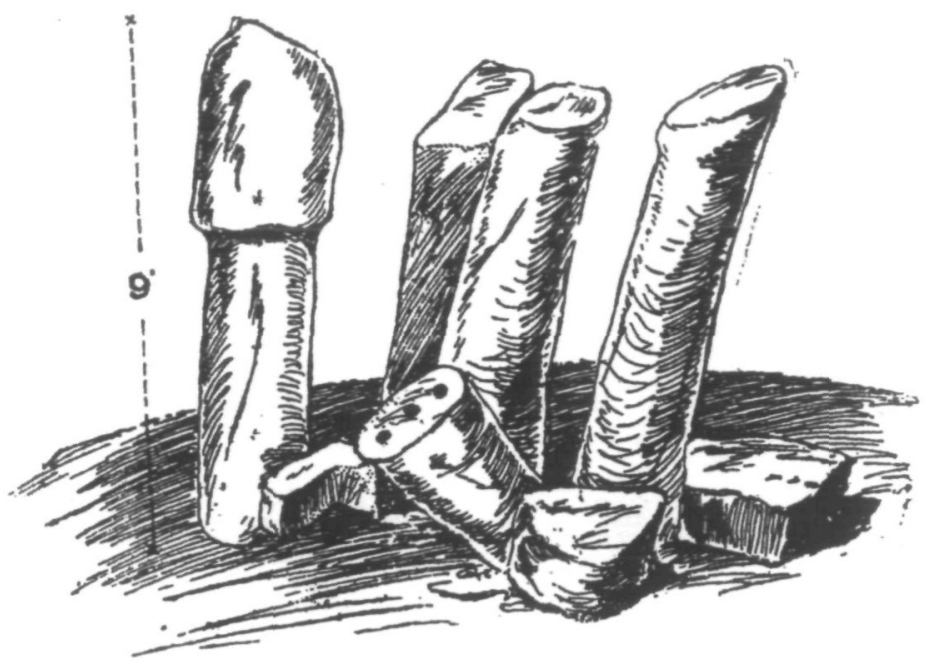

Stone relics, 250 yards from the front of the Oni of Ife's residence. - Sketched and measured on the spot, 28.1.08.

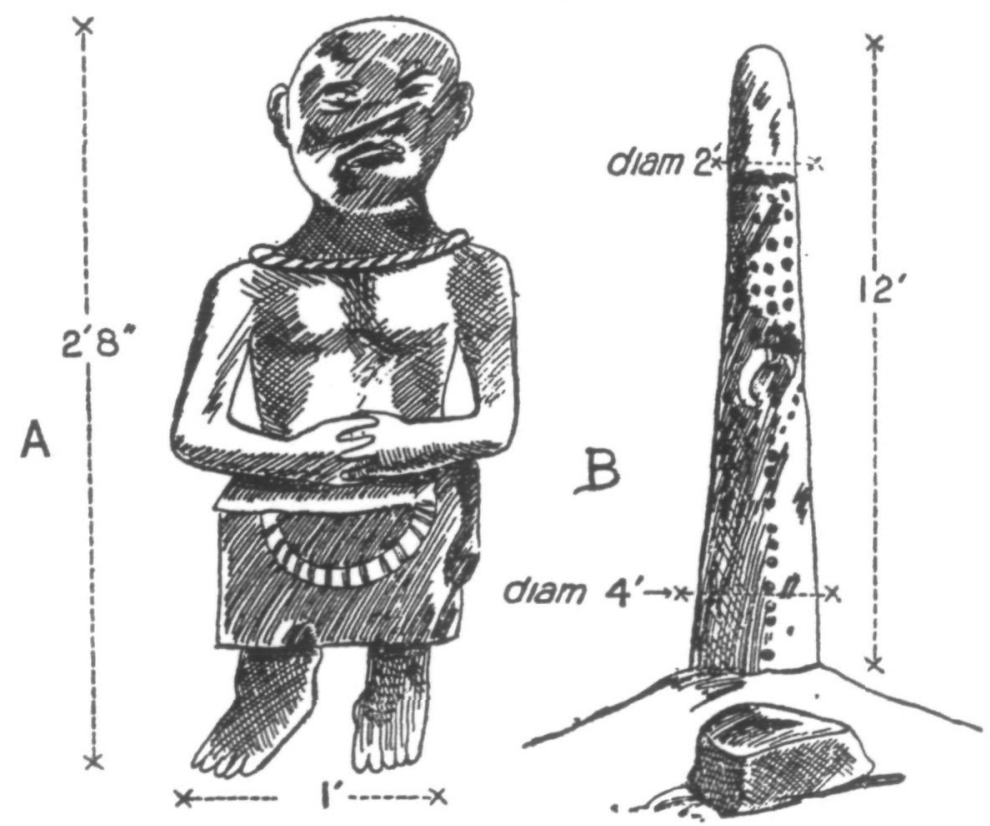

1. Stutuette of gneissic granite, very wuch worn by exposure. Features negroid. Now enshrined in fetich grove, one mile S.E. of Oni's retidence-B. Manalith known as Opa Oranyan, Yorube for "Walking-stick of God." It is of granite and atuded with iron neils 4 inches long. Stands in fetich grove it mile south of Oni's residence. 
(I)

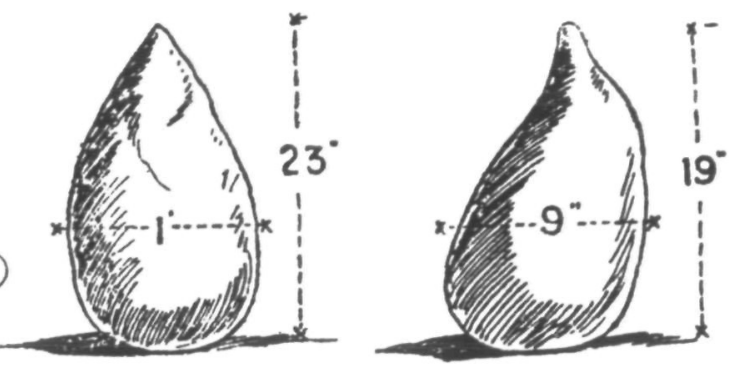

(2)

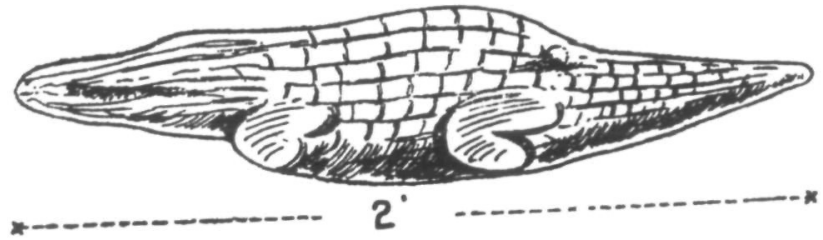

(3)
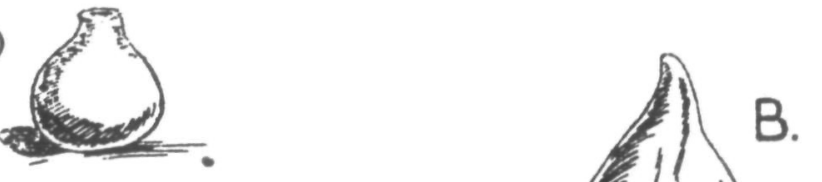

A.

(4)

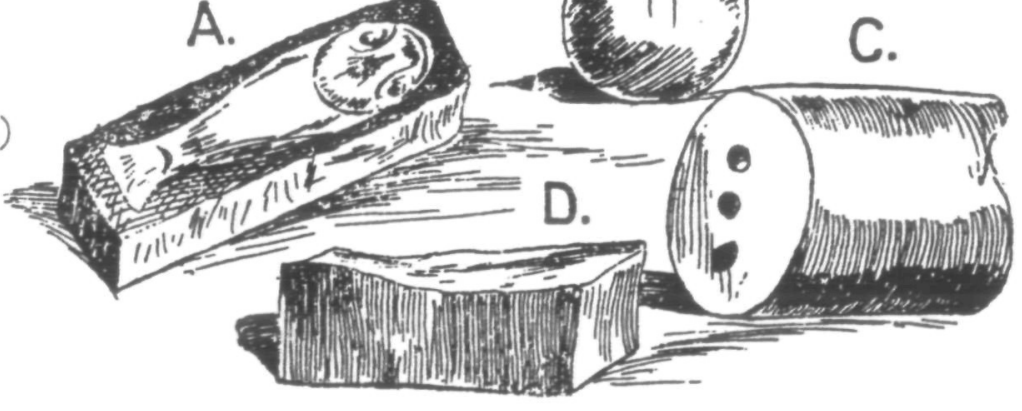

(I) Stones of this shape are numermas: I do not know their original object. Presentday mythology calls them "Grod's anvila"-(2) Alligator carved in gneissic granite-(3) Earthentrare pot: these are found in dozena near every stone carving. - (4) All thexe stone (gmanite) relics are in the compound of the Ife's residence: A. Fish-cupposed to be "a present from God."-B. "God's nnvil" - wupponed to be impossible to move. -C. "God"s forge," let down from beaven (Evidently the section of a pillar, the holes being for iron joiningbars.)-D. "God's whetstone "-for sharpening bis tools,-C. H. ELorR. 
are visible for a radius of two miles round the present town of Ife. Those stone relics which I have seen, and of which I send accurate drawings, are scattered far and wide. The ones light enough to carry are mostly in private houses. Those too heavy are probably in their original positions. In every case fetich groves have been formed round them. Sometimes they have been referred to as the Ife "Marbles." This is incorrect. The stone is either quartz or gneissic granite, both of which abound in the neighbourhood.

I hope to have further opportunities of adding to my researches, but, since a British officer took away with him one of the images, it is difficult for me to obtain a view, as the natives regard every stone of this sort with awe, and are afraid for their own prosperity should one be removed.

I am convinced that the miserable collection which up to now is all that $I$ have been able to see is a poor example of much which remains to be revealed. I hope soon to be able to find inscriptions of some sort which may enable us to identify the creators, and in the meantime send, for what they are worth, the accompanying drawings. A discussion is invited.

C. H. Elgee. 